\title{
TROPICAL FRUITS OF MANGO AND NONI HAVING DUAL EFFECTS OF COAGULATING MILK AND ENRICHING THE CURDS WITH MICRO-CONSTITUENTS OF MEDICINAL POTENTIAL
}

\author{
Jaya Vejayan ${ }^{1 a}$, Norliana Munir ${ }^{2 a}$, Yee Lee Lian ${ }^{3 a}$, Rupbansraaj Bathmanathan ${ }^{4 a}$, \\ Halijah Ibrahim $^{5 b}$ and Srikumar Chakravarthi ${ }^{6 c}$
}

${ }^{a}$ Faculty of Industrial Science \& Technology, Universiti Malaysia Pahang, Lebuhraya Tun Razak, 26300, Gambang, Kuantan, Pahang Darul Makmur, MALAYSIA. Email: jayavejayan@ump.edu.my'; norlianamunir@gmail.com ${ }^{2}$; rupbansraaj@gmail.com ${ }^{4}$;

binstitute of Biological Sciences, University of Malaya, 50603 Kuala Lumpur, MALAYSIA. Email: ihalijah@um.edu.my ${ }^{5}$

${ }^{c}$ Graduate School of Medicine, Perdana University, Block B and D1, MAEPS Building, MARDI Complex Jalan MAEPS Perdana, 43400 Seri Kembangan, Selangor, MALAYSIA. Email: srikumar@ mahsa.edu.my ${ }^{6}$

*Corresponding author: jayavejayan@ump.edu.my

Received: $9^{\text {th }}$ May $2019 \quad$ Accepted: $12^{\text {th }}$ Sep 2019

Published: $31^{\text {st }}$ Dec 2019

DOI: https://doi.org/10.22452/mjs.vol38no3.4

\begin{abstract}
Plants are capable of coagulating milk efficiently and enriching the curd with medicinal potentials, which can result in an ideal functional dairy food. Such efforts were attempted within this study with two fruit bearing plants, Mango (Mangifera indica) and Noni (Morinda citrifolia). The extracts of the two plants were separated to their enzymatic fractions and investigated for their coagulating time in comparison to rennet enzyme of Mucor miehei. The biological activities of the curd formed by the extracts were evaluated to determine the antioxidant and antidiabetic activities. The coagulation of milk by $M$. indica seed fraction, $M$. citrifolia fruit fraction and the rennet $(15 \%, 15 \%$, and $5 \%(\mathrm{w} / \mathrm{v})$, respectively) resulted in coagulation times of $10.8 \pm 0.36 \mathrm{~s}, 40.73 \pm 1.91 \mathrm{~s}$ and $198.2 \pm 1.01 \mathrm{~s}$, respectively. Curd by aqueous extract of $M$. indica seeds resulted in the most favourable values: $\mathrm{IC}_{50}=3.266 \pm 0.353 \mu \mathrm{g} / \mathrm{mL}$ (2,2-diphenyl-1picylhydrazyl, DPPH), $147.329 \pm 1.890 \mathrm{mg} \mathrm{GAE} / \mathrm{g}$ (Ferric Reducing Antioxidant Power, FRAP), IC $_{50}=17.87 \pm 0.415 \mu \mathrm{g} / \mathrm{mL}$ ( $\alpha$-glucosidase inhibition) and $\mathrm{IC}_{50}=41.87 \pm 0.585 \mu \mathrm{g} / \mathrm{mL}(\alpha$-amylase inhibition). Hence, $M$. indica seed and $M$. citrifolia fruit extracts were tested, and both plant extracts, together with curd-fortification, exhibited useful biological activities.
\end{abstract}

\begin{abstract}
ABSTRAK Tumbuhan herba mampu mengentalkan susu segar kepada dadih dan seterusnya memperkayakannya dengan aktiviti biologi berguna bagi penghasilan makanan tenusu berfungsi. Usaha-usaha seperti ini telah dicuba dalam kajian ini dengan dua buah tanaman berbuah; Morinda citrifolia dan Mangifera indica. Ekstrak kedua-dua tumbuhan telah dipisahkan kepada pecahan enzimatik mereka dan diselidiki kebolehan untuk pengentalan susu berbanding dengan enzim rennet daripada sumber Mucor miehei. Aktiviti biologi dadih yang dibentuk oleh ekstrak telah dinilai untuk menentukan aktiviti antioksidan dan antidiabetik. Kebolehan pengentalan susu oleh fraksi kromatografi daripada $M$. indica, $M$. citrifolia dan rennet $(15 \%, 15 \%$ dan $5 \%(\mathrm{w} / \mathrm{v})$ masing-masing menghasilkan masa pengentalan singkat seperti berikut, $10.8 \pm 0.36 \mathrm{~s}, 40.73 \pm 1.91$ s dan $198.2 \pm 1.01 \mathrm{~s}$, masing-masing. Dadih diperkuat dengan ekstrak berair biji $M$. indica menghasilkan nilai yang paling baik: $\mathrm{IC}_{50}=3.266 \pm 0.353 \mu \mathrm{g} / \mathrm{mL}$ (2,2-diphenyl-1-picylhydrazyl, $\mathrm{DPPH}), 147.329 \pm 1.890 \mathrm{mg}$ GAE / g (FRAP), $\mathrm{IC}_{50}=17.87 \pm 0.415 \mu \mathrm{g} / \mathrm{mL}$ (rencatan $\alpha-$ glucosidase) dan $\mathrm{IC}_{50}=41.87 \pm 0.585 \mu \mathrm{g} / \mathrm{mL}$ (rencatan $\alpha$-amylase). Kesimpulannya, biji $M$. indica dan ekstrak buah $M$. citrifolia diuji, dan kedua-dua ekstrak tumbuhan, selain kebolehan untuk mengental susu juga mempamerkan aktiviti biologi yang berguna.
\end{abstract}

Keywords: functional dairy food, antioxidant, antidiabetic, plant rennet, enzyme 


\section{INTRODUCTION}

Milk-clotting is an initial and essential process in the yogurt- and cheesemaking dairy industries. There are many milk coagulation techniques, including the use of enzymes (either in isolated form or in crude mixtures) to cleave the proteins in milk, resulting in undissolved particles (Jacob et al, 2011). Conventionally, crude rennet obtained from calves has been used in traditional cheese production (Sinaga et al, 2017). Nevertheless, the use of calf rennet has been considered unethical due to the slaughtering of un-weaned animals. To fulfil the high demand for dairy products, efforts to use alternatives has led to the use of large-scale industrial enzymes obtained from microbes, including enzymes from the controversial and debatable genetically modified (GMO) microbes (Csutak and Sarbu, 2018; Hang et al, 2017; Raftari et al, 2017). Other producers have resorted to attaining proteolytic enzymes from plantbased sources, although generally in smaller quantities (Liburdi et al, 2018; Shah, et al, 2014). Such endeavours have been justified to satisfy vegetarian consumers and the large number of Muslim halal customers, which is a market that is estimated to be worth over one trillion dollars (Lubis, et al, 2016).

Foods with a combined use as medicine and food have been recognized recently as functional foods. Consumers are being more conscientious about their choice of functional food ingredients due to health motivations. Among the most promising targets for functional food science are gastrointestinal functions, redoxand antioxidant systems, and the metabolism of macronutrients (Roberfroid, 2000). Many definitions of functional foods exist currently, but the definition that has been developed after much consideration is as follows: "natural or processed foods that contain known or unknown biologically active compounds, which, in defined and effective non-toxic amounts, provide a clinically proven and documented health benefit for the prevention, management, or treatment of chronic disease" (Martirosyan and Singh, 2015).

Only a few plants are capable of coagulating milk efficiently and enriching the curd with micro-constituents with medicinal potentials, which can result in an ideal functional dairy food. Such efforts were attempted within this study with two fruit bearing plants that have shown such dual potentials. One plant extract was obtained from common agricultural waste, i.e., the seeds of a mango (Mangifera indica) variant, while the other extract was obtained from a popular fruit known as noni (Morinda citrifolia L.) or by the local name "mengkudu". The fruit of $M$. citrifolia contain valuable organic compounds, with the plant exhibiting widespread growth as well as various biological activities such as antibacterial, antiviral, antifungal, antitumour, anthelminthic, analgesic, hypotensive, anti-inflammatory, antioxidant, antidiabetic and immune enhancing effects (Assi et al, 2017; Inada et al, 2017). Mango ( $M$. indica) is another important domestic plant with numerous medicinal benefits that have been exhibited by its by-products, i.e., seeds (Jahurul et al, 2015). 


\section{MATERIAL AND METHOD}

Sample: Mangifera indica (a variety known in Malay as Mangga epal) and $M$. citrifolia were obtained from cultivators and their voucher specimens were deposited at the Institute of Biological Sciences, University of Malaya with numbers of HI 1445 and HI 1446, respectively. The seed (seed coat removed) of $M$. indica (MIs) and the fruit of $M$. citrifolia (MCf) were washed thoroughly to remove unwanted contaminants and were then cut into pieces.

Extraction: MCf juice was extracted by squeezing the fruits using muslin cloth. The juice that was obtained was filtered using muslin cloth and was further clarified by filter paper (Whatman No. 1, SigmaAldrich, USA) and freeze dried. While, MIs were dried to a constant weight at a temperature of $50^{\circ} \mathrm{C}$ in an oven for three days. A total of $4 \mathrm{~g}$ of dried MIs sample powder was suspended in deionized water, homogenized with a magnetic stirrer for three hours, filtered using muslin cloth, and further clarified by filtration using filter paper (Whatman No. 1). After filtering, the crude extracts obtained were almost completely concentrated by a rotary evaporator followed by freeze drying.

Removal of micro-constituents to obtain enzymatic fractions: To enable study on enzymatic coagulant only each extract was removed from its micro-constituents using a PD-10 Desalting Column (GE Healthcare, USA) with a molecular weight exclusion of $5000 \mathrm{Da}$. Then, $2 \mathrm{ml}$ of each fraction was collected and read using a spectrophotometer at $280 \mathrm{~nm}$. A graph plot based on the absorbance readings was created to obtain only the protein portion. The tubes containing protein were pooled, freeze dried, and the protein concentration was determined. The pooled fractions were assumed to include the macro-constituent portion with enzymes and were denoted as $M$. indica seed fraction (MIsf) and $M$. citrifolia fruit fraction (MCff).

Determining the milk coagulation capabilities: A total of $15 \%(\mathrm{w} / \mathrm{v})$ samples of both MIsf and MCff were prepared in 1 $\mathrm{ml}$ of water. A rennet solution of $5 \%(\mathrm{w} / \mathrm{v})$ was also prepared. These preparations were added to $1 \mathrm{ml}$ of $10 \%$ (w/v) skim milk, and the initial milk coagulation end points were determined based on three visible parameters, i.e., viscosity, colour changes, and the development of white spots (Nájera et al, 2003). The latter was determined by evaluating the morphological changes of the structure of a drop of milk under a light microscope (Nikon Eclipse E100, USA, fitted with a digital imager, DinoEye Eyepiece Camera Software) once the initial positive evaluations of the other two parameters (viscosity and colour changes) were observable. The coagulation time recorded once spotted under microscope the first appearance of graininess in the moving film of milk (Ruzaina Ishak et al, 2006). Additionally, selected freeze-dried specimens (curd formed by MIsf, MCff, rennet, and milk alone) were subjected to SEM (Fei Quanta 450, Thermo Fisher Scientific, USA) analysis at the Central Laboratory, Universiti of Malaysia, Pahang, Malaysia.

Milk Clotting Activity (MCA): MCA value was determined by using $10 \%$ (w/v) skim milk (BD Difco ${ }^{\mathrm{TM}}$, USA) in $0.05 \mathrm{M}$ $\mathrm{CaCl}_{2}$ as a substrate (Shata, 2005). A total of $5 \mathrm{ml}$ milk at $40^{\circ} \mathrm{C}$ added with $0.5 \mathrm{ml}$ of test samples, and then the counting time started. The time at which the first particles formed was recorded. One unit of milkclotting activity (U) was defined as the amount of enzyme required to coagulate 1 $\mathrm{ml}$ of substrate in 40 minutes at $40^{\circ} \mathrm{C}$. MCA was calculated according to the following formula: 


$$
\mathrm{U}=\frac{2400}{T} \times \frac{S}{E}
$$

where $\mathrm{T}(\mathrm{s})$ is the time needed for clot formation, $\mathrm{S}$ is the volume of skim milk $(\mathrm{ml})$ at a concentration of $10 \%(\mathrm{w} / \mathrm{v})$ and $\mathrm{E}$ is the volume of MIsf, MCff, or rennet (MIsf and MCff, 15\% (w/v) and rennet, 5\% $(\mathrm{w} / \mathrm{v}))$.

Proteolytic activity (PA): The PA value of the test samples determined as described by Cupp-Enyard (2008) with minor modifications. Briefly, $1 \%$ casein in potassium phosphate buffer ( $\mathrm{pH} 7.5$ ) was added to $300 \mu 1$ of the test samples of either $15 \%(\mathrm{w} / \mathrm{v})$ MIsf, $15 \%(\mathrm{w} / \mathrm{v})$ MCff or $5 \%$ $(\mathrm{w} / \mathrm{v})$ rennet, and the mixture was incubated for 30 minutes at $35^{\circ} \mathrm{C}$. The reaction was stopped by adding $5 \mathrm{ml}$ of $0.11 \mathrm{M}$ TCA. The reaction mixture was then centrifuged at $10,000 \mathrm{rpm}$ for 15 minutes. A total of 2 $\mathrm{ml}$ of the supernatant was collected and mixed with $0.5 \mathrm{M}$ sodium carbonate. Next, $0.5 \mathrm{mM}$ Folin's reagent was added, and the

\section{Determination of the antioxidant activities}

\section{2,2-diphenyl-1-picylhydrazyl (DPPH)} assay: The $\mathrm{IC}_{50}$ for the $\mathrm{DPPH}$ assay was calculated by plotting the percentage of inhibition against the concentrations of the curd samples (Alothman et al, 2009). A standard curve of gallic acid $(\mathrm{R} \& \mathrm{M}$ Chemicals, UK) was prepared. An ethanol solution was used as a blank, and a mixture of $500 \mu \mathrm{l}$ of $0.04 \% \quad(\mathrm{w} / \mathrm{v}) \quad \mathrm{DPPH}$ mixture was incubated at $35^{\circ} \mathrm{C}$ for 30 minutes. A tyrosine standard was prepared with $1 \mathrm{mM}$ tyrosine standard stock solution. Both reaction tests and the tyrosine standard test were subjected to absorbance reading at $660 \mathrm{~nm}$.

Preparation of curd samples to determine the biological activities: Curd was obtained by coagulating $10 \%$ (w/v) skim milk (BD DifcoTM USA) with 5\% (w/v) of the crude plant extracts, MCf and MIs (inclusive of their micro-constituents, i.e., constituents with molecular weights < $5 \mathrm{kDa})$, and rennet. The aggregated reconstituted skim milk was centrifuged at room temperature to achieve a clear separation between the curd (pellet) and whey (supernatant). The curd formed was collected for freeze drying.

(Calbiochem, USA) was used as a control. Reaction mixtures consisted of $500 \mu \mathrm{L}$ of curd and $500 \mu \mathrm{L}$ of $0.004 \%$ (w/v) DPPH solution, which were mixed and pipetted into a 96-well microtiter plate and incubated at room temperature for 30 minutes in the dark. After incubation, the absorbance was measured at $517 \mathrm{~nm}$ using Infinite 200 PRO NanoQuant Microplate Readers from Tecan, Switzerland. The antioxidant activity is expressed as the percentage of inhibition by using the following formula:

$$
\text { Inhibition }(\%)=\frac{\mathrm{Abs}_{\text {control }}-\mathrm{Abs}_{\text {sample }}}{\mathrm{Abs}_{\text {control }}} \times 100
$$

where $A_{\text {control }}$ is the absorbance reading of the control reaction, and $\mathrm{A}_{\text {sample }}$ is the absorbance of the sample reaction.

Ferric reducing antioxidant power (FRAP) assay: FRAP value determined as described by Ou et al. (2002) for the curd sample. The standard curve of gallic acid was prepared. Reaction mixtures of $1000 \mu \mathrm{l}$ of curd and $500 \mu \mathrm{l}$ of $1.0 \%(\mathrm{w} / \mathrm{v})$ potassium ferricyanide ( $\mathrm{R} \& \mathrm{M}$ Chemicals, UK) were incubated in a water bath at $50^{\circ} \mathrm{C}$ for 20 minutes, followed by the addition of $500 \mu 1$ of $10 \%(\mathrm{w} / \mathrm{v})$ trichloroacetic acid to stop the 
reaction. The reaction mixtures were then centrifuged, and the supernatant was mixed with $500 \mu \mathrm{l}$ of deionized water and $100 \mu \mathrm{l}$ of $0.1 \%(\mathrm{w} / \mathrm{v})$ ferric chloride before incubation at room temperature for 30 minutes for colour development. The increase in absorbance of the reaction mixture was measured at $700 \mathrm{~nm}$.

\section{Determination of antidiabetic activities}

$\boldsymbol{\alpha}$-amylase inhibitory activity: The screening for the $\alpha$-amylase inhibitory activity of the curd was performed by using the chromogenic dinitrosalicylic acid (DNS) procedure (Ademiluyi and Oboh, 2013). A standard curve of acarbose was prepared. Reaction mixtures of $1000 \mu \mathrm{L}$ of curd and $200 \mu \mathrm{L}$ of $2 \mathrm{U} / \mathrm{mL}$ porcine pancreatic $\alpha$-amylase enzyme (Sigma, UK) in $20 \mathrm{mM}$ sodium phosphate $\mathrm{pH} 6.9$ were incubated at $25^{\circ} \mathrm{C}$ for 30 minutes. After incubation, $200 \mu \mathrm{l}$ of starch solution was added to the reaction mixtures and incubated at $25^{\circ} \mathrm{C}$ for 10 minutes, followed by the addition of $200 \mu \mathrm{l}$ of $96 \mathrm{mM}$ DNS colour reagent in an $85^{\circ} \mathrm{C}$ water bath for 5 minutes to stop the reaction. The absorbance of the resulting mixtures was measured at $540 \mathrm{~nm}$ using a microplate reader. The activity of $\alpha$-amylase inhibition is expressed in terms of the percentage of inhibition, which was calculated as follows:

$$
\alpha \text {-amylase inhibition }(\%)=\frac{\mathrm{Abs}_{\mathrm{control}}-\mathrm{Abs}_{\text {sample }}}{\mathrm{Abs}_{\mathrm{control}}} \times 100
$$

where $A_{\text {control }}$ is the absorbance of the control reaction and $A_{\text {sample }}$ is the absorbance of the curd sample. The doseresponse curves of the percentage of inhibition against the curd sample concentration was plotted, and the $\mathrm{IC}_{50}$ values of the curd sample and acarbose were estimated through interpolation.

$\alpha$-glucosidase inhibitory activity: The $\alpha$ glucosidase inhibition of the curd was determined using the modified version of the method described by Yilmazer-Musa et al (2012). A standard curve of acarbose was prepared. Reaction mixtures of $200 \mu \mathrm{l}$ of curd and $200 \mu \mathrm{l}$ of $\alpha$-glucosidase enzyme
(Sigma, UK) solution from Saccharomyces cerevisiae (1 $\mathrm{U}$ in $67 \mathrm{mM}$ potassium phosphate buffer $\mathrm{pH}$ 6.9) were incubated at $37^{\circ} \mathrm{C}$ for 60 minutes. To initiate the reaction, $200 \mu \mathrm{l}$ of $10 \mathrm{mM}$ p-NPG (Sigma, UK) in $67 \mathrm{mM}$ potassium phosphate buffer pH 6.9 was added and incubated at $37^{\circ} \mathrm{C}$ for 20 minutes. A total of $300 \mu \mathrm{L}$ of $100 \mathrm{mM}$ sodium carbonate was added to stop the reaction. The $\alpha$-glucosidase activity was ascertained by measuring the yellow colour of p-nitrophenol released from p-NPG at $405 \mathrm{~nm}$ using a microplate reader. The percentage of $\alpha$-glucosidase inhibition was determined by using the following formula:

$$
\alpha \text {-glucosidase inhibition }(\%)=\frac{\mathrm{Abs}_{\text {control }}-\mathrm{Abs}_{\text {sample }}}{\mathrm{Abs}_{\text {control }}} \times 100
$$

where $A b s_{\text {control }}$ is the absorbance of the control reaction and Abs sample is the absorbance of the curd sample. The doseresponse curves of the percentage of inhibition against the curd sample concentration was plotted, and the $\mathrm{IC}_{50}$ values of the curd sample and acarbose were estimated through interpolation. 
Spectrometry analysis of curds: The curd samples coagulated by MCf and MIs were analysed using liquid chromatography / quadrupole time-of-flight mass spectrometry (LC / Q-TOF / MS). The analysis of the curd samples was performed using a Vion IMS QTof Mass Spectrometer (Waters Corp., USA) equipped with an ACQUITY UPLC I-Class UPLC system and a QTof detector. The UNIFI scientific information system software was used for data acquisition, processing, and reporting.

\section{RESULTS}

Removal of micro-constituents with molecular weights $<5$ kDa: The initial removal of micro-constituents with molecular weights $<5 \mathrm{kDa}$ using a PD-10 column is shown in Figure 1. Only pooled protein fractions (maximum absorption at an OD of $280 \mathrm{~nm}$ ) were used for the milk coagulation studies. The protein concentrations of the pooled fractions were $0.832 \pm 0.02 \mathrm{mg} / \mathrm{ml}$ and $0.072 \pm 0.003$ $\mathrm{mg} / \mathrm{ml}$ in MIsf and MCff, respectively, as estimated using the Bradford assay.
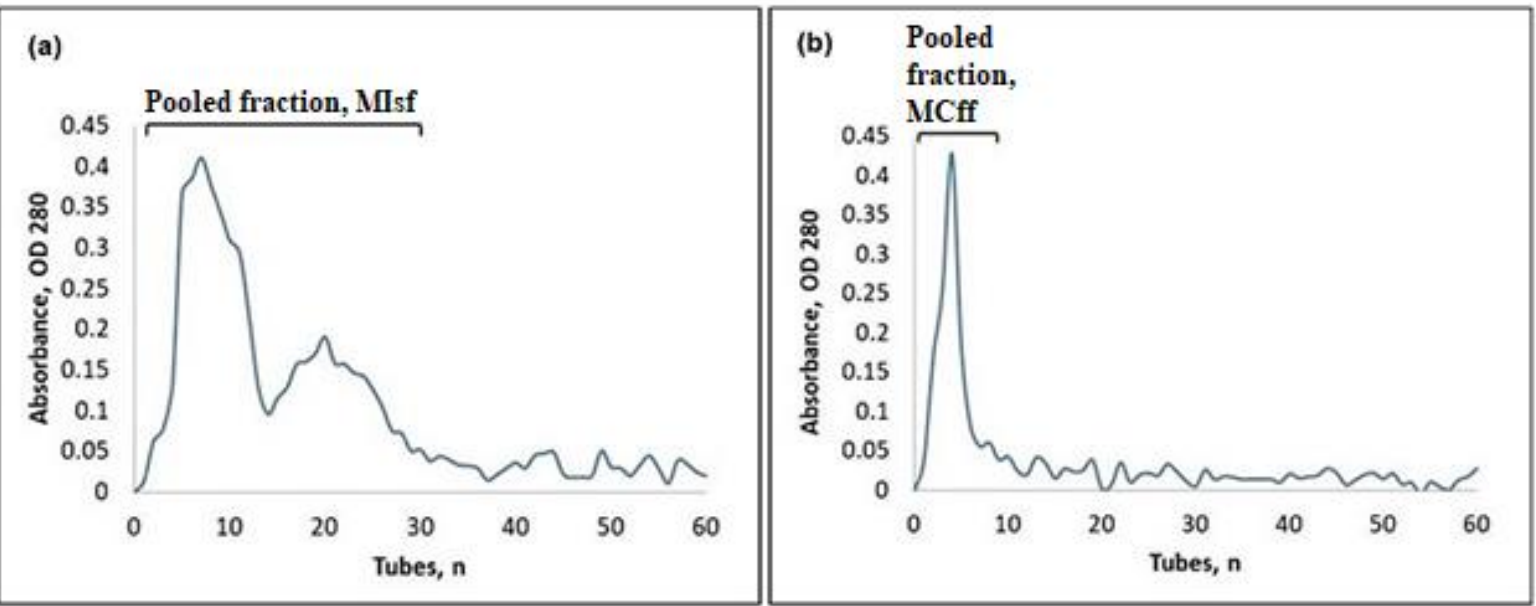

Figure 1. Graph of absorbance (measured at $280 \mathrm{~nm}$ ) of tubes on fractions obtained from MIs (a) and MCf (b) crude extracts.

Milk coagulation time of pooled fractions (macro-constituents): The milk coagulation time, PA, MCA, and ratio of the pooled fractions of MIsf and MCff (without micro-constituents $<5 \mathrm{kDa}$ ) as well as of rennet are shown in Table 1. MCff showed the most rapid coagulating activity, followed by MIsf. The $\mathrm{pH}$ levels measured for MIsf and MCff were both in the acidic range. MIsf was found to have a comparable ratio of MCA/PA as that of the MCff, while both were significantly lower than that of rennet.

Table 1. Parameters of milk coagulation by MIsf, MCff and rennet

\begin{tabular}{cccccc}
\hline Samples/enzymes & $\begin{array}{c}\mathbf{p H} \\
\text { measured }\end{array}$ & $\begin{array}{c}\text { Coagulation } \\
\text { time } \\
\text { (seconds) } \\
\text { Mean } \pm \mathbf{S E}\end{array}$ & $\begin{array}{c}\text { Clottting } \\
\text { activity } \\
(\mathbf{U} / \mathbf{m l})\end{array}$ & $\begin{array}{c}\text { Proteolytic } \\
\text { activity } \\
\text { (U/ml) }\end{array}$ & $\mathbf{R}$ \\
\hline M. indica & $4.71 \pm 0.01$ & $40.73 \pm 1.91$ & $1371.46 \pm 4.52$ & $1.38 \pm 0.00$ & 993.8 \\
$\begin{array}{c}\text { M. } \text { citrifolia } \\
\text { rennet }\end{array}$ & $4.03 \pm 0.02$ & $10.8 \pm 0.36$ & $889.99 \pm 30.86$ & $0.98 \pm 0.00$ & 908.2 \\
$($ M. meihei $)$ & $5.43 \pm 0.03$ & $198.2 \pm 1.01$ & $121.08 \pm 0.62$ & $0.03 \pm 0.00$ & 4036.0 \\
\hline
\end{tabular}

Data presented as SE with repeats of $n=3$. The end point was recorded when discrete particles were observed. $\mathrm{R}=$ Milk clotting activity / proteolytic activity 
Microscopic View of Samples: Notable differences were observed in three observations (after centrifugation, at low magnification and with scanning electron microscopy) between the coagulated and uncoagulated milk (Figure 2).

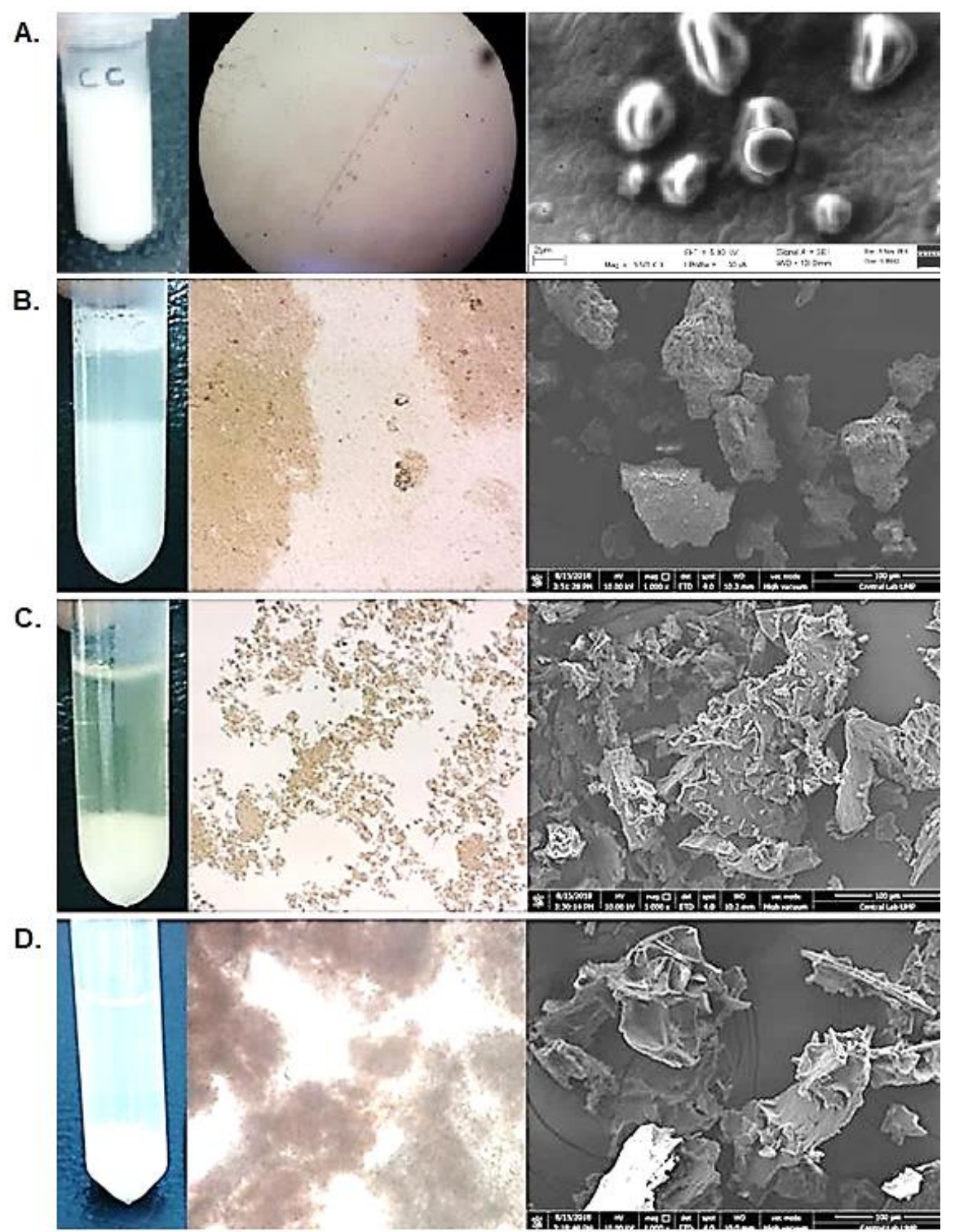

Figure 2. Pre- and post-coagulation of milk. Panel A shows a tube of milk without any coagulant added (control), the structure of the milk at low magnification (100X) viewed under light microscopy (centre), and an SEM image of freeze-dried milk (right) at 3.5KX. Panel B shows a tube of milk containing a clear separation between whey and curd (observed after centrifugation at $10,000 \mathrm{rpm}$ for 2 minutes) after coagulation by $M$. indica, the structure milk that was coagulated by $M$. indica at low magnification (100X) viewed under light microscopy (centre), and an SEM image of freeze-dried curd (right) at $1 \mathrm{KX}$. Panel C and

Panel D show milk that was coagulated by $M$. citrifolia and rennet, respectively.

The image of the freeze-dried milk, viewed under scanning electron microscopy, showed similar individual structures of casein micelles. The micelles exhibited a round, spherical shape and were distributed evenly throughout the milk sample. The image of the caseinate curd resulting from MIsf showed strong shadowing effects due to surface roughness as a result of the development of strands of 
gel formed due to coagulation. The particle surfaces showed clumps of uneven surfaces that formed compact structures. Caseinate curds of MCff and rennet showed uneven, irregular clumps with much larger hollow spaces, which appeared as large globular particles emerging from their interior and forming a thread of networks.

\section{Antioxidant activities}

DPPH Assay: Table 2 summarizes the $\mathrm{IC}_{50}$ values for the DPPH assay on curds obtained from crude plant extracts of MIs and MCf. The antioxidant activity increased as the concentration of the samples increased (Figure 3A). Curds produced from milk coagulated with rennet could not ascertain any $\mathrm{IC}_{50}$ value as unable to scavenge up to $50 \%$ of the free radicals in the reaction. While, $M$. indica showed the lowest $\mathrm{IC}_{50}$ value hence with the most prominent antioxidant activity, which was almost comparable to that of gallic acid.

FRAP Assay: Gallic acid was used as a standard for the calibration curve, as shown in Figure 3B. Table 2 summarizes the total phenolic content of each curd fortified with crude plant extracts. Curd fortified with aqueous crude extracts of MIs and MCf demonstrated significant ferric reducing antioxidant potential, with $M$. indica having the most prominent antioxidant activity with the highest phenolic content.

Table 2. Summary for the measurements of the biological activities of the various curds

\begin{tabular}{|c|c|c|c|c|}
\hline Curd samples & $\begin{array}{c}\text { DPPH, } \\
\text { IC }_{50}(\mu \mathrm{g} / \mathrm{ml})\end{array}$ & $\begin{array}{c}\text { FRAP, } \\
\text { Total Phenolic } \\
\text { Content (mg } \\
\text { GAE/g) }\end{array}$ & $\begin{array}{c}\alpha \text {-amylase } \\
\text { inhibitory } \\
\text { activity, } \\
\text { IC } C_{50}(\mu \mathrm{g} / \mathrm{ml})\end{array}$ & $\begin{array}{c}\alpha \text {-glucosidase } \\
\text { inhibitory } \\
\text { activity, } \\
\text { IC } C_{50}(\mu \mathrm{g} / \mathrm{ml})\end{array}$ \\
\hline M. indica & $3.266 \pm 0.353$ & $147.329 \pm 1.890$ & $41.87 \pm 0.585$ & $17.87 \pm 0.415$ \\
\hline $\begin{array}{l}\text { M. citrifolia } \\
\text { rennet } \\
\text { (M. meihei) }\end{array}$ & $\begin{array}{c}214.5 \pm 0.529 \\
\text { ND }\end{array}$ & $\begin{array}{c}16.869 \pm 0.581 \\
\text { ND }\end{array}$ & $\begin{array}{c}1469.0 \pm 0.620 \\
\text { ND }\end{array}$ & $\begin{array}{c}41.14 \pm 0.453 \\
\mathrm{ND}\end{array}$ \\
\hline Gallic acid & $2.548 \pm 0.523$ & 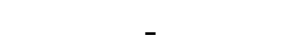 & - & - \\
\hline Acarbose & - & 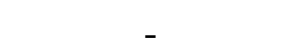 & $49.77 \pm 0.477$ & $3.358 \pm 0.454$ \\
\hline
\end{tabular}

Data presented as SE with repeats of $n=3$. ND denotes not detectable.

A

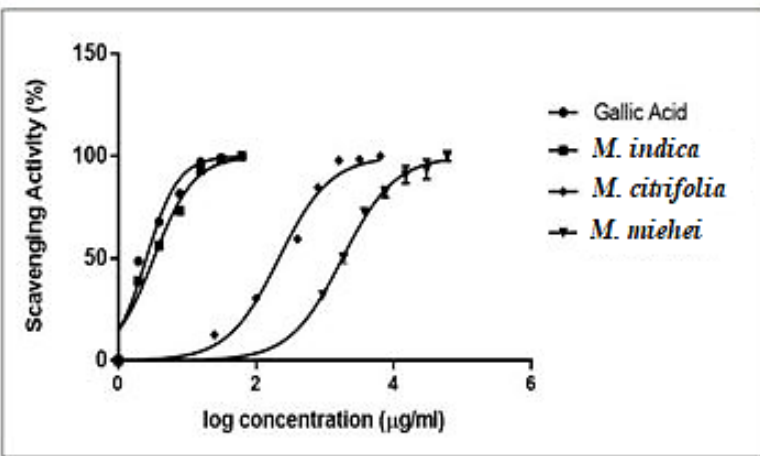

B

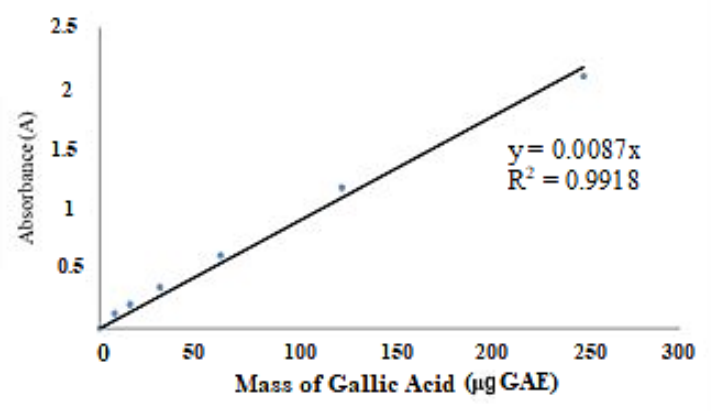


C

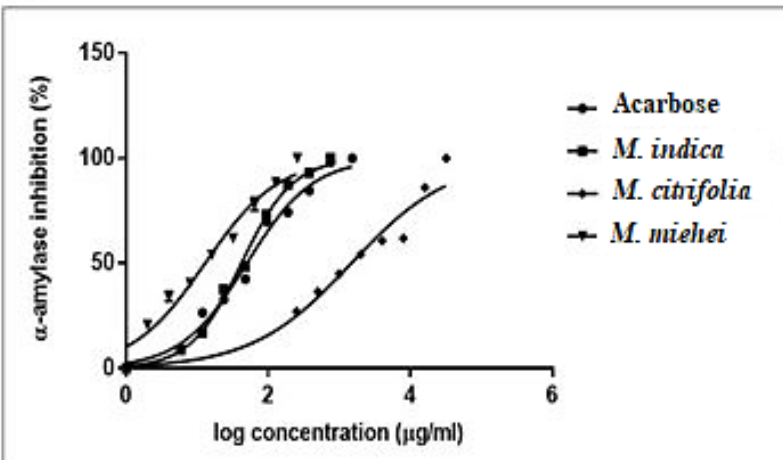

D

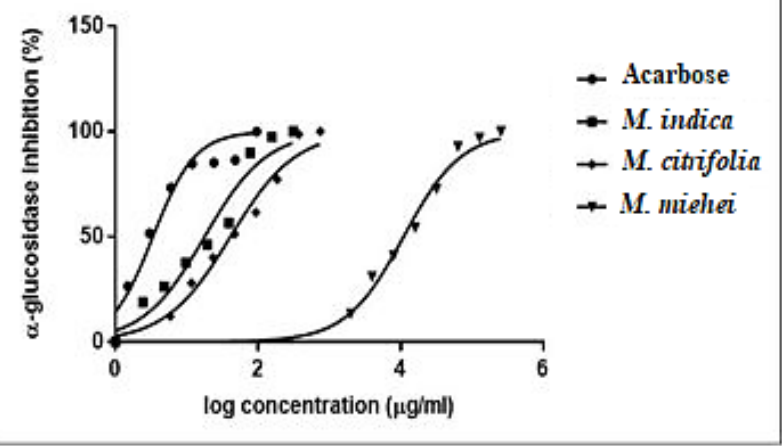

Figure 3. Graphs of A. a combination of scavenging activity (\%) and log concentrations of gallic acid, MIs curds, MCf curds and rennet curds; B. calibration curve of absorbance against mass of gallic acid; $\mathbf{C}$. percentage of $\alpha$-amylase inhibitory activity against log concentrations of acarbose, MIs, MCf and rennet curds; $\mathbf{D}$. percentage of $\alpha$-glucosidase inhibitory activity against concentrations of acarbose, MIs, MCf, and rennet curds.

\section{Antidiabetic activities}

$\alpha$-amylase inhibitory activity: The $\alpha$ amylase inhibitory activity of the curds was examined by using the standard acarbose as shown in Figure 3C. Table 2 shows the inhibitory activity of $\alpha$-amylase of each curd fortified with crude aqueous extracts of the selected plants. The curd fortified with crude aqueous extract of MIs showed the most significant $\alpha$-amylase inhibitory activity, which was even superior to that of the acarbose standard. The curd produced by rennet expressed the lowest $\alpha$-amylase inhibitory activity with no meaningful $\mathrm{IC}_{50}$.

$\alpha$-glucosidase inhibitory activity: The $\alpha$ glucosidase inhibitory activity of the curds was examined by using the standard acarbose, as shown in Figure 3D. Table 2 shows the inhibitory activity of $\alpha$ glucosidase on curd fortified with aqueous crude plant extracts. Curds of MIs showed a strong inhibitory activity against $\alpha$ glucosidase, though the activity was not as strong as that of acarbose. The curd produced from milk coagulated with rennet expressed the lowest $\alpha$-glucosidase inhibitory activity and did not show any meaningful $\mathrm{IC}_{50}$.

\section{Spectrometry Identification of known} Antioxidant and Anti-diabetic compounds in curds: LC-Q-Tof-MS analysis of curds derived from both plants showed the presence of compounds that were selectively matched to antioxidant and anti-diabetic-grouped compounds within the two libraries included with the equipment. The libraries were Natural Product Synthetic Adulterants and Traditional Chinese Medicine. Table 3 shows the relevant compounds. The possible presence of four biologically active compounds were detected in MIs compared to MCf with only two.

Table 3. Relevant compounds matched by the LC / Q-ToF / MS in the curd samples of MCf, and MIs based on libraries of antidiabetic and antioxidant.

\begin{tabular}{cccccc}
\hline $\begin{array}{c}\text { Curd } \\
\text { samples }\end{array}$ & RT (min) & $\begin{array}{c}\text { Observed } \\
\text { Mass }(\mathbf{m} / \mathbf{z})\end{array}$ & $\begin{array}{c}\text { Area of } \\
\text { Peak }\end{array}$ & $\begin{array}{c}\text { Molecular } \\
\text { Formula }\end{array}$ & $\begin{array}{c}\text { Compounds } \\
\text { matched }\end{array}$ \\
\hline MIs & 0.41 & 325.1440 & 24740 & $\mathrm{C}_{20} \mathrm{H}_{20} \mathrm{O}_{4}$ & $\begin{array}{c}\text { Bavachin } \\
\text { (Corylifolin) } \\
\end{array}$ \\
& 5.98 & 453.2740 & 3670 & $\mathrm{C}_{27} \mathrm{H}_{36} \mathrm{~N}_{2} \mathrm{O}_{4}$ & \begin{tabular}{c} 
Repaglinide \\
\hline
\end{tabular} \\
\hline
\end{tabular}




\begin{tabular}{|c|c|c|c|c|c|}
\hline \multirow{4}{*}{$\mathrm{MCf}$} & 15.89 & 307.0796 & 1273 & $\mathrm{C}_{15} \mathrm{H}_{14} \mathrm{O}_{7}$ & $\begin{array}{c}(-)- \\
\text { Epigallocatechin }\end{array}$ \\
\hline & 16.46 & 402.3495 & 1171 & $\mathrm{C}_{27} \mathrm{H}_{46} \mathrm{O}_{2}$ & $\delta$-Tocopherol \\
\hline & 0.41 & 324.1364 & 22319 & $\mathrm{C}_{20} \mathrm{H}_{20} \mathrm{O}_{4}$ & $\begin{array}{c}\text { Bavachin } \\
\text { (Coryliforin) }\end{array}$ \\
\hline & 3.96 & 261.0532 & 6158 & $\mathrm{C}_{15} \mathrm{H}_{10} \mathrm{O}_{3}$ & Flavonol \\
\hline
\end{tabular}

\section{DISCUSSION}

The plants studied initially had all micro-constituent less than $5 \mathrm{kDA}$ removed to evaluate the ability of the plant to cleave milk proteins; this was done mostly because plant proteases are generally larger (Gagaoua et al, 2015). Apart from proteolytic coagulation, milk is known to coagulate as a result of exposure to low $\mathrm{pH}$ levels. The plants mostly contained low molecular weight constituents, inclusive of those with acidic functional groups. The results revealed that $M$. citrifolia had the most rapid coagulation time compared to those of $M$. indica and rennet. The ratio of milk coagulation activity to proteolytic activity (MCA/PA) is a crucial benchmark in determining the peptidase potential to be used as coagulants in cheese industry (Arima et al, 1970; Freitas et al, 2016). In addition, the ratio is regarded as an index to assess possible rennet substitutions (Hashim et al, 2011). Theoretically, plant rennet with a higher ratio of MCA/PA is more capable of producing good curd with higher yield as well as less bitterness compared to one with a low MCA/PA ratio, which affects the sensory properties of the cheese in the final stage (Amira et al, 2017; Mazorra-Manzano et al, 2013). It was observed that both $M$. indica and $M$. citrifolia, assessed by their macromolecules, showed a lower ratio of MCA/PA only compared to rennet. However, $M$. indica had a slightly higher ratio than that of $M$. citrifolia. The higher ratio of rennet (a pure isolate) compared to both plants (being partially purified proteases) was expected. Hashim et al (2011) reported a protease isolated from ginger with a ratio of 1653 . The fruit of $M$. citrifolia displayed bromelain-like enzyme activity, especially when a casein substrate was used (Golden and Smith-Marshall, 2012). In addition, a study on $M$. citrifolia also obtained results demonstrating that there was a protease enzyme present in the M. citrifolia fruit (Ismail and Abd Razak, 2014). Nevertheless, no specific study found a correlation with the mango variant used in this study.

The curd of $M$. indica shown excellent antioxidant activity in the current study. Research has highlighted the antioxidant properties of mango seed kernel, which is normally discarded when the fruit is processed; studies have demonstrated that an aqueous seed kernel extract of $M$. indica showed potent DPPH radical scavenging activity with a lower half inhibition concentration ( $\mathrm{IC}_{50}$ ) value equal to $2.14 \mu \mathrm{g} / \mathrm{ml}$ comparable with those of the reference compounds, namely, vitamin $\mathrm{C}$, trolox and BHA (Maisuthisakul and Gordon, 2009). The antioxidant effect of the mango seed kernel was due to the high content of polyphenols, sesquiterpenoids and tocopherols (Schieber et al, 2003). Another report identified the presence of gallic and ellagic acids and gallates (Dorta et al, 2014). The similar IC 50 values of the aqueous crude seed kernel extract of mango and its fortified curd also reflected the efficient retention of the crude seed kernel extract.

Curd fortified with a crude aqueous extract of $M$. citrifolia exhibited the lowest antioxidant properties in comparison with the antioxidant properties of the other extracts, as evaluated in the DPPH radical scavenging assay, with an inhibitory 
concentration of a $50 \%\left(\mathrm{IC}_{50}\right)$ value of $214.5 \pm 0.529 \mu \mathrm{g} / \mathrm{ml}$, i.e., an antioxidant activity approximately 65 times lower than that of the MIs extract. A study conducted showed that the $\mathrm{IC}_{50}$ value of aqueous $M$. citrifolia fruit extract was only 369.37 $\mu \mathrm{g} / \mathrm{ml}$, which was categorized as a moderate antioxidant (Tsai et al, 2007). The results of the FRAP assay were in agreement with the outcome of the DPPH experiments, in which the MIs extract had the highest antioxidant activity followed by that of the MCf extract. Research reported by Mireles-Arriaga et al (2016) suggested that the phytochemical screening of the crude aqueous fruit extract of noni $(M$. citrifolia) possessed a total phenolic content of $22.76 \mathrm{mg} \mathrm{GAE} / \mathrm{g}$, which was similar to the results obtained for the total phenolic content of the curd fortified with the crude aqueous fruit extract of noni $(16.869 \pm 0.581 \mathrm{mg} \mathrm{GAE} / \mathrm{g})$, suggesting the high capability of fortified curd to retain the antioxidant content even though the liquid whey was discarded from the semi-solid curd by centrifugation. The results obtained from both assays suggested that curds fortified with crude aqueous extracts of $M$. indica and $M$. citrifolia were appreciated for their good milk-coagulating abilities as well as for being a source of antioxidants.

The curd derived from the $M$. indica extract exhibited prominent $\alpha$-amylase inhibitory activity $\left(\mathrm{IC}_{50}=41.87 \pm 0.585\right.$ $\mu \mathrm{g} / \mathrm{ml}$ ). Irondi et al (2014) reported similar results in which aqueous mango seed extracts effectively inhibited $\alpha$-amylase in a dose-dependent manner with an $\mathrm{IC}_{50}$ of approximately $37.86 \pm 0.32 \mu \mathrm{g} / \mathrm{ml}$. The ability of the curd produced by the crude fruit extract of $M$. citrifolia had a higher $\mathrm{IC}_{50}$ value $(1469.0 \pm 0.620 \mu \mathrm{g} / \mathrm{ml})$. The results obtained from a previous study demonstrated that a crude aqueous extract of $M$. citrifolia exhibited in vitro $\alpha$-amylase inhibitory activity with an $\mathrm{IC}_{50}$ value of $3800 \mu \mathrm{g} / \mathrm{ml}$ (Assi et al, 2017).
The $\mathrm{IC}_{50}$ values for $\alpha$-glucosidase inhibition remained highest for the curd produced by the $M$. indica extract $(17.87 \pm$ $0.415 \mu \mathrm{g} / \mathrm{ml}$ ) followed by the curd produced by the extract of $M$. citrifolia. Ganogpichayagrai et al (2017) reported similar results in which both mango peel and seed extracts had potential to inhibit $\alpha$-glucosidase with an $\mathrm{IC}_{50}$ value of approximately $11.93 \mu \mathrm{g} / \mathrm{ml}$, which was almost similar to that of the curd produced with the crude aqueous extract of the mango seed. The mango seed is the major waste product of mango after processing, but it is a promising source of therapeutic health benefits (Jahurul et al, 2015).

The possible presence of bavachin, repaglinide, epigallocatechin and $\delta$ tocopherol, while bavachin and flavanol were present in curds produced by MIs and MCf, respectively, provided justification for the antioxidant and anti-diabetic activities. These phenolic compounds identified based on most appropriate matching to natural product libraries compromising compounds belonging to antioxidant and anti-diabetic activities found within the LC / Q-TOF / MS equipment. A literature searches on the antioxidant and anti-diabetic activities of these compounds resulted in the discovery of many articles related to their antioxidant and anti-diabetic activities. For instance, $\delta$ tocopherol has dual anti-diabetic and antioxidant activities (Ratnam et al, 2017). Phenolic fractions have been shown to have antioxidant activity in $M$. citrifolia (Mohd et al, 2006). Similarly extracts of the mango seed kernel containing phenolic components were found to exhibit high antioxidant activity (Jahurul et al, 2015). Hence, it can be generalized that these phenolic compounds were able to enrich the curds once the crude extracts of the plants were exposed to the milk to coagulate. 


\section{CONCLUSION}

Both $M$. indica and M. citrifolia demonstrated dual capabilities of coagulating milk and acting as health supplements. This was evident upon comparison to rennet, which was found to have milk coagulation activity without any significant biological activities in its curd. $M$. indica demonstrated better biological activities compared to those of $M$. citrifolia, but the latter exhibited a faster coagulating time. Ideally for the purpose of functional foods, sources with dual potentials should be derived from waste as demonstrated by the use of the $M$. indica seed in this study. However, further studies on the toxicity of the curds produced should be investigated especially the curd formed from the seeds of $M$. indica which may contain toxic compounds.

\section{ACKNOWLEDGEMENT}

The study funding by Universiti Malaysia Pahang grants mainly by RDU180375, partially by PGRS1901201 and PGRS180354.

\section{REFERENCES}

Ademiluyi AO., and Oboh G. (2013). Soybean phenolic-rich extracts inhibit key-enzymes linked to type 2 diabetes ( $\alpha$-amylase and $\alpha$-glucosidase) and hypertension (angiotensin I converting enzyme) in vitro. Experimental and Toxicologic Pathology 65(3): 305-309. DOI: 10.1016/j.etp.2011.09.005

Alothman M., Bhat R., and Karim A. (2009). Antioxidant capacity and phenolic content of selected tropical fruits from Malaysia, extracted with different solvents. Food Chemistry 115(3): 785-788. DOI: https://doi.org/10.1016/j.foodchem.20 08.12.005
Amira AB., Makhlouf I., Petrut RF., Francis F., Bauwens J., Attia H., Besbes S., and Blecker C. (2017). Effect of extraction $\mathrm{pH}$ on technofunctional properties of crude extracts from wild cardoon (Cynara cardunculus L.) flowers. Food chemistry 225: 258-266. DOI: 10.1016/j.foodchem.2017.01.040

Arima K., Yu J., and Iwasaki S. (1970). Milk-clotting enzyme from Mucor pusillus var. Lindt, in Methods in enzymology. 1970, Elsevier. p 446459.

DOI: https://doi.org/10.1016/00766879(70)19033-1

Assi RA., Darwis Y., Abdulbaqi IM., Khan AA., Vuanghao L., and Laghari MH. (2017). Morinda citrifolia (Noni): A comprehensive review on its industrial uses, pharmacological activities, and clinical trials. Arabian Journal of Chemistry 10(5): 691-707. DOI: https://doi.org/10.1016/j.arabjc.2015.0 6.018

Csutak O., and Sarbu I. (2018). Genetically Modified Microorganisms: Harmful or Helpful?, in Genetically Engineered Foods. Elsevier. p. 143-175. DOI: https://doi.org/10.1016/B978-0-12811519-0.00006-6

Cupp-Enyard C. (2008). Sigma's nonspecific protease activity assay-casein as a substrate. J Vis Exp: JoVE 19: 899. DOI: $10.3791 / 899$

Dorta E., González M., Lobo MG., Sánchez-Moreno C., and de Ancos B. (2014). Screening of phenolic compounds in by-product extracts from mangoes (Mangifera indica L.) by HPLC-ESI-QTOF-MS and multivariate analysis for use as a food ingredient. Food Research International 57: 51-60. DOI: 
https://doi.org/10.1016/j.foodres.2014. 01.012

Freitas, CDT., Leite HB., Oliveira JPB., Amaral JL., Egito AS., Vairo-Cavalli S., Lobo MDP., Monteiro-Moreira ACO., and Ramos MV. (2016). Insights into milk-clotting activity of latex peptidases from Calotropis procera and Cryptostegia grandiflora. Food Research International 87: 50-59. DOI: 10.1016/j.foodres.2016.06.020

Gagaoua M., Hoggas N., and Hafid K. (2015). Three phase partitioning of zingibain, a milk-clotting enzyme from Zingiber officinale Roscoe rhizomes. International journal of biological macromolecules 73: 245-252. DOI: https://doi.org/10.1016/j.ijbiomac.201 4.10.069

Ganogpichayagrai A., Palanuvej C., and Ruangrungsi N. (2017). Antidiabetic and anticancer activities of Mangifera indica cv. Okrong leaves. Journal of advanced pharmaceutical technology \& research 8(1): 19. DOI: $10.4103 / 2231-4040.197371$

Golden K., and Smith-Marshall, J. (2012). Characterization of bromelain from Morinda citrifolia (Noni). Journal of Scientific Research 4(2): 445-445. DOI: https://doi.org/10.3329/jsr.v4i2.8125

Hang F., Wang Q., Hong Q., Gao C., Zhang H., and Chen W. (2017). Structural insight into a novel neutral metalloproteinase from Paenibacillus spp. BD3526: Implications for mechanisms of rapid inactivation and calcium-dependent stability. International journal of biological macromolecules 95: 1082-1090. DOI: 10.1016/j.ijbiomac.2016.10.098

Hashim MM., Mingsheng D., Iqbal MF., and Xiaohong C. (2011). Ginger rhizome as a potential source of milk coagulating cysteine protease. Phytochemistry 72(6): 458-464. DOI: 10.1016/j.phytochem.2010.12.002

Inada AC., Figueiredo PS., Santos-Eichler RAD., Freitas KDC., Hiane PA., Castro APD., and Guimarães RDCA. (2017). Morinda citrifolia Linn.(Noni) and its potential in obesity-related metabolic dysfunction. Nutrients 9(6), 540. DOI: 10.3390/nu9060540

Irondi EA., Oboh G., Akindahunsi AA., Boligon AA., and Athayde ML. (2014). Phenolic composition and inhibitory activity of Mangifera indica and Mucuna urens seeds extracts against key enzymes linked to the pathology and complications of type 2 diabetes. Asian Pacific Journal of Tropical Biomedicine 4(11): 903-910. DOI:

https://doi.org/10.12980/APJTB.4.201 414B364

Ismail N., and Abd Razak N. (2014). Characterization and purification of protease extracted from two maturity stages of 'Noni'(Morinda citrifolia L.) fruit. Scientific Research Journal 11(2): 1-16. DOI: https://doi.org/10.24191/srj.v14i2.542 0

Jacob M., Jaros D., and Rohm H. (2011). Recent advances in milk clotting enzymes. International journal of dairy technology 64(1): 14-33. DOI: https://doi.org/10.1111/j.14710307.2010.00633.x

Jahurul MHA., Zaidul ISM., Ghafoor K., Al-Juhaimi FY., Nyam KL., Norulaini NAN., Sahena F., and Mohd Omar AK. (2015). Mango (Mangifera indica L.) by-products and their valuable components: A review. Food chemistry 183: 173-180. DOI: 10.1016/j.foodchem.2015.03.046 
Liburdi K., Spinelli SE., Benucci I., Lombardelli C., and Esti M. (2018). A preliminary study of continuous milk coagulation using Cynara cardunculus flower extract and calf rennet immobilized on magnetic particles. Food chemistry 239: 157-164. DOI: 10.1016/j.foodchem.2017.06.093

Lubis HN., Mohd-Naim NF., Alizul NN., and Ahmed MU. (2016). From market to food plate: Current trusted technology and innovations in halal food analysis. Trends in Food Science \& Technology 58: 55-68. DOI: https://doi.org/10.1016/j.tifs.2016.10.0 24

Maisuthisakul P., and Gordon MH. (2009). Antioxidant and tyrosinase inhibitory activity of mango seed kernel by product. Food Chemistry 117(2): 332341 .

DOI:

DOI:

10.1016/j.foodchem.2009.04.010

Martirosyan DM., and Singh J. (2015). A new definition of functional food by FFC: what makes a new definition unique? Functional foods in health and disease 5(6): 209-223. DOI: 10.31989/ffhd.v5i6.183

Mazorra-Manzano MA., Perea-Gutiérrez TC., Lugo-Sánchez ME., RamirezSuarez JC., Torres-Llanez MJ., González-Córdova AF., and VallejoCordoba B. (2013). Comparison of the milk-clotting properties of three plant extracts. Food chemistry 141(3): 19021907.

DOI:

10.1016/j.foodchem.2013.05.042

Mireles-Arriaga AI., Ruiz-López II., Hernández-Garciá PA., EspinosaAyala E., López-Martínez LX., and Marquez-Molina O. (2016). The impact of convective drying on the color, phenolic content and antioxidant capacity of noni (Morinda citrifolia L.). Food Science and Technology
36(4): $\quad$ 583-590. DOI:

http://dx.doi.org/10.1590/1678-

457x.00415

Mohd Z., Abdul Hamid A., Osman A., and Saari N. (2006). Antioxidative activities of chromatographic fractions obtained from root, fruit and leaf of Mengkudu (Morinda citrifolia L.). Food Chemistry 94(2): 169-178. DOI: https://doi.org/10.1016/j.foodchem.20 04.08.048

Nájera A., De Renobales M., and Barron L. (2003). Effects of $\mathrm{pH}$, temperature, $\mathrm{CaCl}_{2}$ and enzyme concentrations on the rennet-clotting properties of milk: a multifactorial study. Food Chemistry 80(3): $\quad 345-352 . \quad$ DOI: https://doi.org/10.1016/S03088146(02)00270-4

Ou B., Huang D., Hampsch-Woodill M., Flanagan JA., and Deemer EK. (2002). Analysis of antioxidant activities of common vegetables employing oxygen radical absorbance capacity (ORAC) and ferric reducing antioxidant power (FRAP) assays: a comparative study. Journal of agricultural and food chemistry 50(11): 3122-3128. DOI: $10.1021 /$ jf0 